\title{
Influence of forest management on soil organic carbon stocks
}

\author{
Damian Łabęda, Marek Kondras* \\ Warsaw University of Life Sciences - SGGW, Institute of Agriculture, Department of Soil Sciences, 159 Nowoursynowska Str., 02-776 Warszawa, \\ Poland \\ * Dr inż. M. Kondras, marek_kondras@sggw.edu.pl, ORCID iD: https://orcid.org/0000-0002-1987-7983
}

Received: June 27, 2017

Accepted: May 22, 2020

Associated editor: J. Lasota

\section{Keywords}

Forest management

Carbon stocks

Carbon sequestration

Soils

\begin{abstract}
In this study, physical and chemical soil analyses were carried out on six habitas in the Tuczno State Forest District. The basic objective of the research was be to define the impact of natural habitat fertility, manner of forest utilization and history of use on the volume of the accumulated carbon dioxide in a hectar of soil. An attempt was made to evaluate the stock of organic carbon in every genetic horizon and the whole profiles of selected soils and one countedtrophic soil index (SIG) indicator. In the examined soils, particle size distributions, content and organic carbon storage capacity were analysed together with total nitrogen, C:N ratio, soil reaction and sorption properties. Beech forest stand formed from the undergrowth and saplings after removal of pine stands accumulated over $20 \%$ more organic carbon content than a pine stand with the same uprising history. The influence of beech underwood on the increase of organic carbon stocks in soils is noted. The studies have shown the post-arable influence on the organic carbon stocks. In post agricultural soils, the organic carbon stock was much lower (the average stock of organic carbon was $55.53 \mathrm{Mg} \cdot \mathrm{ha}^{-1}$ ) than in forest soils that were not subject to agriculture (averagely $101.23 \mathrm{Mg} \cdot \mathrm{ha}^{-1}$ ).
\end{abstract}

\section{Introduction}

As commonly known, land-use sector, land-use change and forestry (LULUCF) all absorb and emit carbon dioxide. Thus carbon is absorbed from the atmosphere and stored in trees and other plants, in soil and in timber. In turn, carbon dioxide is emitted due to deforestation, forest degradation and human economic activity like infrastructure development, expansion of agriculture, soil-use change into pasture lands, fires and agricultural activities (ploughing). The balance of green-house gases in this sector reflects net accumulation as a positive balance means absorption exceeds recorded emission.

Due to global climate change, the function of forests has long been emphasized as a significant and natural complex greenhouse gas reduction system. The Kyoto Protocol and the Paris Agreement include the implementation of forest projects (LULUCF - Land-Use, Land-Use Change, Forestry; Joint Implementation LULUCF JI) the aim of which is increasing the effectiveness of greenhouse gas absorption within, for example, the forestry sector. These activities include afforestation, forest management and management of arable land or reclamation (Decision, 2013). As a result, RMU - Removal Units are established (KOBiZE, 2016). At the same time, the European Council and the European Parliament have stressed the role of the economy in restricting emissions. Due to the specific type of this sector, separate legal provisions are suggested to include the land-use sector to meet
EU reduction goals. The primary goal is creating identical conditions for accounting forest, farming, energetic and other systems. However, this requires an optimized monitoring system and joint reporting (Statement of the Commission of the European Parliament, 2012).

In the case of forest soil carbon concentration, the main factors influencing contentare biochemical processes and their intensity together with plant litterfall gain (Kondraset al., 2012; Jandlet al., 2007; Jobbagy and Jackson 2000). The soil concentration of this element is very variable. It is influenced not only by morphological properties and soil structure but also local and global meteorological factors. Despite numerous attempts to establish the Soil Regions for Europe Map, at this moment this is not possible due to large data variability and significant statistic error (Baritzet al., 2010). Undoubtedly, soils are the largest stock of organic carbon on Earth (Schlesinger, 1997). Poland has proposed introducing units of accumulated RMU emissions, generated by the forest sector in the frame of additional operations conducted by FCF (Forest Carbon Farms) for revenue in the coal market. Therefore this research addresses the problem of the influence of forest management on the volume of organic carbon stock in forest soils. The basic study objective was to specify the impact of the natural habitat fertility and the manner of forest utilization and the history of use on the volume of the accumulated carbon dioxide in a hectar of soil. The selected research plots were in the Tuczno Forest District, where studies between 
1988 and 2018 recorded how forestes and forest soil can be used to reduce the atmospheric carbon dioxide concentration to regenerate these soil, increase their productivity, shape biodiversity and control population dynamics (Szyszko et al., 2019). The research stands presented in the paper are only an excerpt of the research to be presented in subsequent publications.

\section{Materials and methods}

Investigations of soils were conducted in the Tuczno State Forest District. According to the nature-forest division, the District is located in the $1^{\text {st }}$ Baltic Region in the $3^{\text {rd }}$ District of the Wałeckie-Myśliborskie Lakes, in the mesoregions of the Wałeckie Lakes (Strzalina and central and eastern Tuczno) and the Drawska Plain (western Tuczno). Investigations were carried out in six sites, representing the characteristic for this complex forest habitat. The analyzed surfaces were overgrown by various plant communities (Table 1). Sites $1 \mathrm{~b}, 2$, and 16 were overgrown by Leucobryo-Pinetum (Sub-Atlantic fresh pine forest). Site 5 was overgrown by Leucobryo-Pinetum towards Luzulo Pilosae-Fagetum, which is acidophilous lowland beech forest. In site 1a occurs Luzulo Pilosae-Fagetum (acidophilous lowland beech forest) and in site 21 Quercoroboris-Pinetum (continental mixed forest). The stands in sites $1 \mathrm{~b}$ and 16 were in age class III (website 1), in site 5 - in age class IV, in sites $1 \mathrm{a}$ and 21 in age class V, and in site 2 in the oldest age class VI.
The stations 1a (compartment 321c) and 1b (compartment 321f) is composed of two forest stands. The first (1a) one is a 98-year-old (in 2013) beech stand developed from the shrub layer and undergrowth after the removal, 40 years ago, of a 130year-old pine stand planted in the place of natural stands. Soil: Brunic Arenosol, habitat type: fresh mixed broad leaved forest (FMBF). The second forest stand is from 2013, a 40-year-old pine stand formed after the removal, 40 years ago, of a 130-year-old pine stand with the shrub layer and beech undergrowth with the same history, utilisation and lookas stand 1a (Dymitryszyn et al., 2013; website 2). The study plot No. 2 (compartment 339a), pine stand in 2013 at 103 years of age, stocking 0.8, site class (bonitation) 2. Underplanted with beech around 1970. Soil: Albic Brunic Arenosol post agricultural, habitat typefresh: mixed coniferous forest (FMCF) (Dymitryszyn et al., 2013; website 2). Study plot No. 5 (compartment 328a) habitat type was fresh coniferous forest (FCF) in accordance with the forest management plan of 1983. After habitat surveys this was fresh mixed coniferous forest (FMCF) (Forest management plan of 1993) and Albic Brunic Arenosol post agricultural soil. Pine stand at 63 years of age in 2013, stocking 0.6, site class (bonitation) 1.0. In 19791982, the stand was heavily damaged by nun moth attacks and by snowfalls and windbreaks in the following years. The fallen and dead trees were not removed (Dymitryszyn et al., 2013; website 2). Study plot No. 16 (compartment 211) pine stand at 37 years of age in 2013 on post agricultural lands, habitat type fresh mixed broad leaved forest (FMBF). Study plot No. 21 (com-

Table 1

Description of research areas

\begin{tabular}{|c|c|c|c|c|c|c|c|c|c|}
\hline 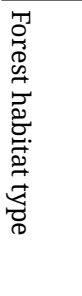 & 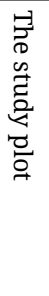 & 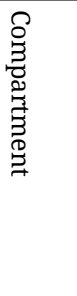 & 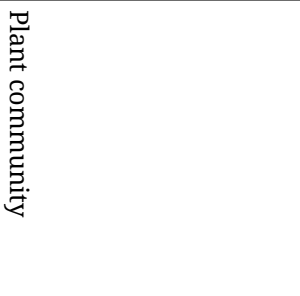 & $\begin{array}{l}\text { T1 } \\
0 \\
0 \\
0 \\
0 \\
0 \\
0 \\
5 \\
0 \\
0\end{array}$ & 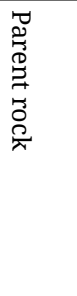 & 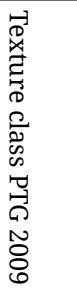 & 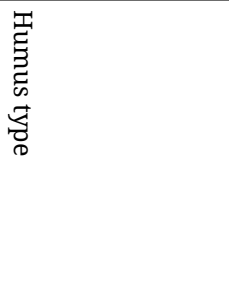 & 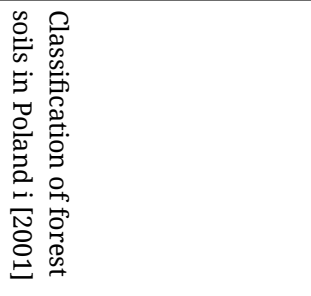 & 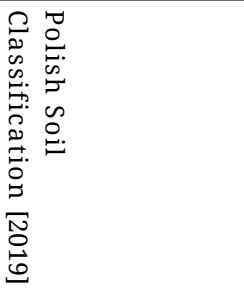 \\
\hline FMBF & $1 \mathrm{a}$ & $321 c$ & Luzulopilosae-Fagetum & $\begin{array}{l}10 \mathrm{Bk}, \\
\text { age } \\
\text { Bk } 98\end{array}$ & Qfgp & sand & moder-mullfresh & $\begin{array}{l}\text { Gleba rdzawa właściwa } \\
\text { (RDw) }\end{array}$ & $\begin{array}{l}\text { Gleba rdzawa } \\
\text { typowa (RWt) }\end{array}$ \\
\hline FMCF & $1 \mathrm{~b}$ & $321 \mathrm{f}$ & Leucobryo-Pinetum & $\begin{array}{l}10 \text { So, } \\
\text { age So40 }\end{array}$ & Qfgp & sand & moder-mor fresh & $\begin{array}{l}\text { Gleba rdzawa bielicowa } \\
\text { (RDb) }\end{array}$ & $\begin{array}{l}\text { Gleba rdzawa } \\
\text { zbielicowana (RVb) }\end{array}$ \\
\hline FMCF & 2 & $339 a$ & Leucobryo-Pinetum & $\begin{array}{l}\text { 10So } \\
\text { age } \\
\text { So103 }\end{array}$ & Qfgp & sand & moder-mor fresh & $\begin{array}{l}\text { Gleba rdzawa bielicowa } \\
(\mathrm{RDb}) \text { porolna }\end{array}$ & $\begin{array}{l}\text { Gleba rdzawa } \\
\text { zbielicowana (RVb) }\end{array}$ \\
\hline FMCF & 5 & $328 a$ & $\begin{array}{l}\text { Leucobryo-Pinetum in } \\
\text { Luzulopilosae-Fagetum }\end{array}$ & $\begin{array}{l}\text { 10So, } \\
\text { age So63 }\end{array}$ & Qfgp & sand & moder-mor fresh & $\begin{array}{l}\text { Gleba rdzawa bielicowa } \\
\text { (RDb) porolna }\end{array}$ & $\begin{array}{l}\text { Gleba rdzawa } \\
\text { zbielicowana (RVb) }\end{array}$ \\
\hline FMCF & 16 & 211 & Leucobryo-Pinetum & $\begin{array}{l}\text { 10So, } \\
\text { age So37 }\end{array}$ & Qfgp & sand & moder-mor fresh & $\begin{array}{l}\text { Gleba rdzawa bielicowa } \\
\text { (RDb) porolna }\end{array}$ & $\begin{array}{l}\text { Gleba rdzawa } \\
\text { zbielicowana (RVb) }\end{array}$ \\
\hline FMBF & 21 & $182 \mathrm{~h}$ & Querco-Pinetum & $\begin{array}{l}8 \mathrm{So} \\
1 \mathrm{Db} \\
1 \mathrm{Brz} \\
\text { age So88 }\end{array}$ & Qfgp & sand & moderfresh & $\begin{array}{l}\text { Gleba rdzawa właściwa } \\
\text { (RDw) }\end{array}$ & $\begin{array}{l}\text { Gleba rdzawa } \\
\text { typowa (RWt) }\end{array}$ \\
\hline
\end{tabular}

FMBF - fresh mixed broad leaved forest, FMCF - fresh mixed coniferous forest, Qfgp - Fluvio-glacial sands, So - Pine, Bk - Beech, Brz - Birch, Db - Oak 
partment 182h) pine stand about 88 years of age in 2013 with a share of oak, beech and birch growing on forest soils in fresh mixed broad leaved forest (FMBF) habitat (Dymitryszyn et al., 2013; website 2).

We conducted soil excavations, morphological descriptions and the systematic position of the soils was defined according to the Classification of forest soils in Poland (Biały et al., 2001), Polish Soil Classification (2019) and according to the FAO-WRB classification (IUSS Working Group WRB, 2015). Forest habitat and plant community were described for each site. Soil samples were collected from the distinguished genetic horizons. Particular parameters were determined using (Ostrowska et al., 1991; Bednarek et al., 2004) grain size composition - Areometric method by Bouyoucos in the modification of Cassagrande and Prószyński, grain size fractions were determined according to PTG (2008); $\mathrm{pH}-$ in $\mathrm{H}_{2} \mathrm{O}$ and $1 \mathrm{M} \mathrm{KCl} \cdot \mathrm{dm}^{-3}$ using the potentiometric method; hydrolytic acidity (Hh) -using the Kappen method; total organic carbon (Corg) using a Shimadzu TOC 5000A automatic analyser; total nitrogen content (Nt) - using the modified Kjeldahl method with application of a Kjeltec-Tecator analyzer; content of exchangeable cations - in an extract of $1 \mathrm{M}$ $\left(\mathrm{CH}_{3} \mathrm{COO}\right) \mathrm{NH}_{4}$; $\mathrm{Ca}$ and $\mathrm{Mg}$ - using the ASA technique; $\mathrm{K}$ and $\mathrm{Na}$ using the flame photometry technique; bulk density of dry soil (BD) in mineral horizons - using the weight method with $100 \mathrm{~cm}^{3}$ cylinders; for organic horizons the bulk density was applied 0.2 $\mathrm{Mg} \cdot \mathrm{m}^{-3}$ after Borek (1983), Janowska and Czępińska-Kamińska (1983) and Karczewska (2007). The following coefficients were calculated with theC: $\mathrm{N}$ ratio; organic carbon stock according to formula $\mathrm{Zp}\left[\mathrm{kg} \cdot \mathrm{m}^{2}\right]=\left[\left(\mathrm{h} \cdot \mathrm{BD} \cdot \mathrm{C}_{\mathrm{org}}\right) / 10\right] \cdot(1-\theta \%)$; whereh - thickness of the horizons ( $\mathrm{cm})$; BD - bulk density $\left(\mathrm{Mg} \cdot \mathrm{m}^{-3}\right) ; \mathrm{C}_{\text {org }}-$ percentage content of organic carbon in a particular horizon; 10 - calculation index of mass and surface units to obtain the result in $\mathrm{kg} \cdot \mathrm{m}^{2} ; \theta$ - percentage of gravel $\emptyset>2 \mathrm{~mm}$ content (Stendhal et al. 2010); base cations ( $\mathrm{BC} \mathrm{Ca}+\mathrm{Mg}+\mathrm{K}+\mathrm{Na}$ ); cation exchange capacity $\mathrm{CEC}=\mathrm{Hh}$ (hydrolityc acidity) $+\mathrm{BC}$ base saturation $\mathrm{BS}=$ $(\mathrm{TEB} / \mathrm{CEC}) \cdot 100$. Using the physical and chemical properties, and following Lasota and Błońska (2013), the SIG (Trophic Soil Index) was calculated for each soil type.

$\mathrm{SIG}=\mathrm{W}_{\mathrm{FP}}+\mathrm{W}_{\mathrm{A}}+\mathrm{W}_{\mathrm{Y}}+\mathrm{W}_{\mathrm{N}}$

where:

$\mathrm{W}_{\mathrm{FP}}$ - index of soil abundance in floatable particles;

$\mathrm{W}_{\mathrm{A}}$ - index of soil abundance in alkaline cations;

$\mathrm{W}_{\mathrm{Y}}$ - index of acidity subdivided by the reserve of floatable particles;

$\mathrm{W}_{\mathrm{N}}$ - index of calculated nitrogen, i.e. $\mathrm{N}_{2 *} \mathrm{C}^{-1}$ in the first mineral horizon.

\section{Results and discussion}

The soils were classified according to the Classification of Forest Soils in Poland (Biały et al., 2001) as Brunic Arenosol (profiles 1a and 21) with a sequence of horizons Ol-Ofh-A-ABvBv-BvC-C and Albic Brunic Arenosol (profiles 1b, 2, 5, 16) with a sequence of horizons Ol-Ofh-AEes-BvBfe-Bv-C. Classification of the studied soils according to other systems as presented in Table 1 . With regard to the varieties of soil subtypes, according to the Classification of Forest Soils in Poland, all profiles fulfil the criteria for oligotrophic soils. When assessing the quality of the studied soils based on the habitat soil index, two trophic varieties of soil subtypes were distinguished: profiles $1 \mathrm{a}$ and 2 were assigned to oligotrophic soils, and the remaining soils were classified as dystrophic soils. According to a synthetic diagnosis including the partial diagnoses from plants (forest stands and undergrowth), the habitats were classified as fresh mixed broad leaved forest (FMBF) in site $1 \mathrm{a}$ and 21 and mixed coniferous forest (FMCF) in sites 1b, 2, 5, and 16. According to anthropogenic features distinguishing the varieties of forest soil subtypes in sites 2, 5 and 16, post-agricultural soils were observed.

The sediments, from which the analyzed Brunic Arenosols and Albic Brunic Arenosols were developed include glacial sands characterised by loose sand fraction only horizon C3 in profile 16 and horizon $\mathrm{C} 1$ in profile 2 had a fraction of sand and loamy sand (Table 2). They are characterized by the largest percentage contribution of three medium (3.17\% to $27.42 \%)$, fine (26.95\% to $56.09 \%)$ and very fine (13.42\% to $42.35 \%)$ sand fractions.

All studied soils had an acidic reaction in the entire profile, although varying among the genetic horizons and subtype types and varieties from very strongly acidic to acidic. The $\mathrm{pH}$ values in $\mathrm{KCl}$ were at 2.47 in site 2 in horizon $\mathrm{Ol}$ to 4.92 in study plot $1 \mathrm{a}$ in horizon $\mathrm{C5}$. With regard to hydrolytic acidity, the ectohumus horizon sat tained values from $32.25 \mathrm{cmol}_{(+)} \cdot \mathrm{kg}^{-1}$ (site $16-\mathrm{Ol}$ ) to $81.23 \mathrm{cmol}_{(+)} \cdot \mathrm{kg}^{-1}$ (site $1 \mathrm{~b}-\mathrm{Ol}$ ) in the organic horizon and from $0.47 \mathrm{cmol}_{(+)} \cdot \mathrm{kg}^{-1}$ (site $1 \mathrm{a}-\mathrm{C} 5$ ) to $8.19 \mathrm{cmol}_{(+)} \cdot \mathrm{kg}^{-1}$ (site $21-\mathrm{A}$ ) in the mineral horizon.

The sorption capacity in the ectohumus horizons was several times higher than in the mineral horizons. The content of particular alkaline cations in all soil profiles was similar, with the exception of site $1 \mathrm{a}$, where the content in the mineral horizon was much higher than in the remaining profiles. This was most probably due to the type and age of the forest stand. The plant litter fall from beech stands enriches the soil in alkaline cations, changing the physico-chemical properties of the organic horizons and the surface mineral horizons (Ilmurzyński and Włoczewski, 2003).

Similar relationships were observed for total nitrogen determination. The largest values were noted in site 21 in horizon $\mathrm{Mb} 1-23.2 \mathrm{~g} \cdot \mathrm{kg}^{-1}$ and in site 2 in the organic horizonsat 17.2 and $15.8 \mathrm{~g} \cdot \mathrm{kg}^{-1}$. In most soil profiles, total nitrogen content was not noted in the parent material. In the analyzed soils, organic carbon is accumulated mainly in the organic and accumulation-humus horizons (Table 4). Rather high reserves were also noted in sideric horizons Bv. Organic carbon was not noted in the parent rock in profiles 2, 5 and 16, and traces occurred in profiles $1 \mathrm{a}$, $1 \mathrm{~b}$ and the biggestin 21 . The organic carbon reserve, beside its content in the soil substrate of each horizon, distinguished in $\mathrm{g} \cdot \mathrm{kg}^{-1}$, also depends on the thickness of this horizon, the density of dry soil and gravel content (> $2.0 \mathrm{~mm}$ ) (Kondras et al., 2012). The species composition (plant community) and the age of the forest stands has a large influence on organic carbon reserves. This factor also has large influence on the vertical distribution of soil profile organic carbon. The analyses indicated that in 
Table 2

Texture of soils

\begin{tabular}{|c|c|c|c|c|c|c|c|c|c|c|c|c|}
\hline \multirow{2}{*}{$\begin{array}{l}\text { The } \\
\text { study } \\
\text { plot }\end{array}$} & \multirow{2}{*}{$\begin{array}{l}\text { Horizon } \\
\text { (depth cm) }\end{array}$} & \multirow{2}{*}{$\begin{array}{l}>2 \mathrm{~mm} \\
{[\%]}\end{array}$} & \multicolumn{9}{|c|}{ Percent of granulometric fractions in diameter in $\mathrm{mm}$} & \multirow{2}{*}{$\begin{array}{l}\text { Texture } \\
\text { class } \\
\text { [PTG 2008] }\end{array}$} \\
\hline & & & $2.0-1.0$ & $1.0-0.5$ & $0.5-0.25$ & $0.25-0.1$ & $0.1-0.05$ & $\begin{array}{l}0.05- \\
-0.02\end{array}$ & $\begin{array}{l}0.02- \\
-0.005\end{array}$ & $\begin{array}{l}0.005- \\
-0.002\end{array}$ & $<0,002$ & \\
\hline \multirow{9}{*}{$1 \mathrm{a}$} & $\mathrm{A}(0-8)$ & 0 & 0 & 7 & 17 & 33 & 37 & 2 & 4 & 0 & 0 & sand \\
\hline & $\mathrm{ABv}(8-19)$ & 0 & 0 & 3 & 12 & 43 & 36 & 2 & 3 & 0 & 0 & sand \\
\hline & Bv1 (19-35) & 2 & 3 & 2 & 12 & 54 & 27 & 2 & 1 & 0 & 0 & sand \\
\hline & Bv2 (35-46) & 3 & 2 & 3 & 12 & 60 & 22 & 2 & 0 & 0 & 0 & sand \\
\hline & C1 (46-70) & 0 & 0 & 1 & 3 & 79 & 16 & 1 & 0 & 0 & 0 & sand \\
\hline & C2 (70-94) & 0 & 0 & 2 & 10 & 68 & 17 & 2 & 0 & 0 & 0 & sand \\
\hline & C3 (94-140) & 0 & 0 & 4 & 14 & 43 & 38 & 0 & 0 & 0 & 0 & sand \\
\hline & C4 (140-190) & 0 & 0 & 3 & 4 & 57 & 32 & 3 & 0 & 0 & 0 & sand \\
\hline & C5 (190-200) & 0 & 0 & 1 & 5 & 76 & 16 & 2 & 0 & 0 & 0 & sand \\
\hline \multirow{6}{*}{$1 \mathrm{~b}$} & AEes (0-10) & 0 & 0 & 3 & 11 & 50 & 32 & 1 & 3 & 0 & 0 & sand \\
\hline & BvBhfe (10-20) & 2 & 2 & 5 & 12 & 51 & 31 & 0 & 0 & 0 & 0 & sand \\
\hline & Bv1 (20-50) & 2 & 2 & 4 & 10 & 58 & 26 & 1 & 0 & 0 & 0 & sand \\
\hline & Bv2 (50-76) & 1 & 3 & 6 & 2 & 43 & 34 & 3 & 0 & 0 & 0 & sand \\
\hline & C1 (76-108) & 0 & 0 & 1 & 8 & 69 & 20 & 2 & 0 & 0 & 0 & sand \\
\hline & C2 (108-180) & 0 & 0 & 1 & 6 & 76 & 13 & 3 & 0 & 0 & 0 & sand \\
\hline \multirow{5}{*}{2} & ApEes (0-21) & 0 & 0 & 3 & 24 & 29 & 42 & 2 & 0 & 0 & 0 & sand \\
\hline & BvBhfe (21-52) & 1 & 1 & 4 & 13 & 39 & 37 & 3 & 4 & 0 & 0 & sand \\
\hline & C1 (dark) (52-110) & 1 & 3 & 8 & 21 & 27 & 30 & 7 & 7 & 0 & 0 & sand \\
\hline & C1 (bright) (52-110) & 0 & 0 & 3 & 12 & 55 & 26 & 5 & 0 & 0 & 0 & sand \\
\hline & C2 (110-180) & 0 & 0 & 2 & 16 & 55 & 23 & 3 & 0 & 0 & 0 & sand \\
\hline \multirow{5}{*}{5} & ApEes (0-21) & 0 & 0 & 4 & 22 & 40 & 26 & 5 & 2 & 1 & 0 & sand \\
\hline & BvBhfe (21-42) & 2 & 2 & 5 & 10 & 54 & 26 & 5 & 0 & 0 & 0 & sand \\
\hline & C1 (42-70) & 0 & 0 & 5 & 10 & 45 & 31 & 8 & 0 & 0 & 0 & sand \\
\hline & C2 (70-120) & 0 & 0 & 5 & 19 & 37 & 32 & 7 & 0 & 0 & 0 & sand \\
\hline & C3 (120-180) & 0 & 0 & 5 & 27 & 27 & 34 & 7 & 0 & 0 & 0 & sand \\
\hline \multirow{7}{*}{16} & ApEes (0-5) & 0 & 0 & 3 & 13 & 51 & 28 & 3 & 1 & 1 & 0 & sand \\
\hline & Ap (5-26) & 0 & 0 & 2 & 14 & 56 & 23 & 3 & 2 & 0 & 0 & sand \\
\hline & BvBhfe (26-51) & 0 & 0 & 3 & 15 & 53 & 28 & 2 & 0 & 0 & 0 & sand \\
\hline & C1 (51-64) & 0 & 0 & 1 & 17 & 56 & 26 & 0 & 0 & 0 & 0 & sand \\
\hline & C2 (64-104) & 0 & 0 & 7 & 23 & 31 & 33 & 4 & 1 & 0 & 0 & sand \\
\hline & С3(104-160) & 0 & 0 & 4 & 18 & 41 & 20 & 17 & 0 & 0 & 0 & loamy sand \\
\hline & C4 (160-200) & 0 & 0 & 1 & 11 & 53 & 19 & 15 & 0 & 0 & 0 & sand \\
\hline \multirow{10}{*}{21} & $\mathrm{~A}(0-11)$ & 0 & 0 & 1 & 7 & 32 & 55 & 2 & 2 & 0 & 0 & sand \\
\hline & $\mathrm{ABv}(11-24)$ & 0 & 0 & 2 & 8 & 33 & 53 & 3 & 1 & 0 & 0 & sand \\
\hline & Bv (24-58) & 0 & 0 & 1 & 8 & 43 & 45 & 2 & 0 & 0 & 0 & sand \\
\hline & C1 (58-95) & 0 & 0 & 1 & 5 & 41 & 50 & 3 & 0 & 0 & 0 & sand \\
\hline & C2 (95-101) & 0 & 0 & 1 & 3 & 33 & 62 & 1 & 0 & 0 & 0 & sand \\
\hline & Mb1 i Mb2 (101-104) & - & - & - & - & - & - & - & - & - & - & - \\
\hline & AEesb (108-125) & 0 & 0 & 3 & 19 & 35 & 41 & 3 & 0 & 0 & 0 & sand \\
\hline & Eesb (125-131) & 0 & 0 & 3 & 20 & 29 & 41 & 7 & 0 & 0 & 0 & sand \\
\hline & BvBfeb (131-162) & 0 & 0 & 3 & 19 & 35 & 41 & 2 & 1 & 0 & 0 & sand \\
\hline & $\mathrm{Cb}(162-200)$ & 0 & 0 & 2 & 19 & 39 & 35 & 4 & 0 & 0 & 0 & sand \\
\hline
\end{tabular}


Table 3

Selected soil physico-chemical properties

\begin{tabular}{|c|c|c|c|c|c|c|c|c|c|c|c|c|}
\hline \multirow{2}{*}{$\begin{array}{l}\text { The plot } \\
\text { study }\end{array}$} & \multirow[b]{2}{*}{ Horizon } & \multirow{2}{*}{$\begin{array}{l}\text { Depth } \\
{[\mathrm{cm}]}\end{array}$} & \multicolumn{2}{|l|}{$\mathrm{pH}$} & \multicolumn{7}{|c|}{$\left[\mathrm{cmol}_{(+)} \mathrm{kg}^{-1}\right]$} & \multirow[b]{2}{*}{ BS [\%] } \\
\hline & & & in $\mathrm{H}_{2} \mathrm{O}$ & in KCI & $\mathrm{Hh}^{*}$ & $\mathrm{Ca}^{2+}$ & $\mathrm{Mg}^{2+}$ & $\mathrm{K}^{+}$ & $\mathrm{Na}^{+}$ & $\mathrm{BC}$ & CEC & \\
\hline \multirow[t]{11}{*}{$1 \mathrm{a}$} & $\mathrm{Ol}$ & $0-1$ & 4.21 & 4.01 & 39.45 & 31.42 & 7.25 & 0.97 & 0.12 & 39.76 & 79.21 & 50.2 \\
\hline & Ofh & $1-3.5$ & 4.13 & 3.99 & 48.20 & 27.64 & 2.25 & 0.63 & 0.09 & 30.61 & 78.81 & 38.8 \\
\hline & A & $0-8$ & 4.21 & 4.00 & 6.31 & 1.04 & 0.12 & 0.42 & 0.04 & 1.62 & 7.93 & 20.4 \\
\hline & $\mathrm{ABv}$ & 8-19 & 4.53 & 3.81 & 4.13 & 0.55 & 0.05 & 0.05 & 0.03 & 0.68 & 4.81 & 14.1 \\
\hline & Bv1 & $19-35$ & 4.73 & 4.43 & 2.75 & 0.05 & 0.00 & 0.03 & 0.02 & 0.10 & 2.85 & 3.5 \\
\hline & Bv2 & $35-46$ & 4.64 & 4.41 & 2.10 & 0.12 & 0.02 & 0.03 & 0.02 & 0.19 & 2.29 & 8.3 \\
\hline & $\mathrm{C} 1$ & $46-70$ & 4.99 & 4.74 & 0.83 & 0.12 & 0.02 & 0.02 & 0.01 & 0.17 & 1.00 & 17.0 \\
\hline & $\mathrm{C} 2$ & $70-94$ & 4.67 & 4.72 & 0.71 & 0.13 & 0.02 & 0.02 & 0.00 & 0.17 & 0.88 & 19.3 \\
\hline & $\mathrm{C} 3$ & $94-140$ & 4.96 & 4.72 & 0.62 & 0.02 & 0.00 & 0.02 & 0.00 & 0.04 & 0.66 & 6.1 \\
\hline & $\mathrm{C} 4$ & $140-190$ & 5.58 & 4.73 & 0.57 & 0.32 & 0.04 & 0.03 & 0.00 & 0.39 & 0.96 & 40.6 \\
\hline & $\mathrm{C} 5$ & $190-200$ & 5.91 & 4.92 & 0.47 & 0.33 & 0.05 & 0.02 & 0.01 & 0.41 & 0.88 & 46.5 \\
\hline \multirow[t]{8}{*}{$1 \mathrm{~b}$} & $\mathrm{Ol}$ & $0-1$ & 3.65 & 2.83 & 81.23 & 24.17 & 7.32 & 1.11 & 0.19 & 32.79 & 114.02 & 28.8 \\
\hline & Ofh & $1-7$ & 3.75 & 2.98 & 70.65 & 17.32 & 1.37 & 0.85 & 0.09 & 19.54 & 90.28 & 21.7 \\
\hline & AEes & $0-10$ & 4.30 & 3.64 & 5.75 & 0.33 & 0.01 & 0.07 & 0.02 & 0.43 & 6.18 & 6.9 \\
\hline & BvBhfe & $10-20$ & 4.68 & 4.30 & 3.47 & 0.06 & 0.01 & 0.04 & 0.01 & 0.12 & 3.59 & 3.3 \\
\hline & Bv1 & $20-50$ & 4.91 & 4.59 & 1.61 & 0.04 & 0.00 & 0.04 & 0.01 & 0.09 & 1.70 & 5.2 \\
\hline & Bv2 & $50-76$ & 4.72 & 4.45 & 0.96 & 0.03 & 0.00 & 0.03 & 0.01 & 0.07 & 1.03 & 6.8 \\
\hline & $\mathrm{C} 1$ & 76-108 & 4.81 & 4.56 & 0.83 & 0.06 & 0.00 & 0.04 & 0.01 & 0.11 & 0.94 & 11.6 \\
\hline & $\mathrm{C} 2$ & $108-180$ & 5.04 & 4.43 & 0.71 & 0.16 & 0.01 & 0.03 & 0.01 & 0.21 & 0.92 & 22.7 \\
\hline \multirow[t]{7}{*}{2} & $\mathrm{Ol}$ & $0-2$ & 2.91 & 2.47 & 73.35 & 21.60 & 0.63 & 0.88 & 0.33 & 23.44 & 96.79 & 24.2 \\
\hline & Ofh & $2-10$ & 2.93 & 2.55 & 58.46 & 16.64 & 0.53 & 0.23 & 0.15 & 17.55 & 76.01 & 23.1 \\
\hline & ApEes & $0-21$ & 4.84 & 4.29 & 2.76 & 0.24 & 0.03 & 0.04 & 0.02 & 0.33 & 3.09 & 10.7 \\
\hline & BvBhfe & $21-52$ & 5.03 & 4.60 & 1.77 & 0.16 & 0.02 & 0.04 & 0.03 & 0.25 & 2.02 & 12.4 \\
\hline & $\mathrm{C} 1$ & $52-110$ & 5.04 & 4.05 & 1.47 & 0.87 & 0.38 & 0.24 & 0.00 & 1.49 & 2.96 & 50.4 \\
\hline & $\mathrm{C} 1$ & $52-110$ & 4.98 & 4.48 & 1.35 & 0.06 & 0.01 & 0.05 & 0.00 & 0.12 & 1.47 & 8.2 \\
\hline & $\mathrm{C} 2$ & $110-180$ & 5.54 & 4.57 & 0.83 & 0.27 & 0.04 & 0.06 & 0.00 & 0.37 & 1.20 & 30.8 \\
\hline \multirow[t]{7}{*}{5} & $\mathrm{Ol}$ & $0-1$ & 4.02 & 3.89 & 77.32 & 23.24 & 1.03 & 1.00 & 0.16 & 25.43 & 102.75 & 24.8 \\
\hline & Ofh & $1-6$ & 4.13 & 3.95 & 74.55 & 11.47 & 0.99 & 0.67 & 0.17 & 13.30 & 87.85 & 15.1 \\
\hline & ApEes & $0-21$ & 4.84 & 4.30 & 3.23 & 0.07 & 0.01 & 0.03 & 0.03 & 0.14 & 3.37 & 4.1 \\
\hline & BvBhfe & $21-42$ & 5.27 & 4.69 & 1.64 & 0.19 & 0.02 & 0.03 & 0.03 & 0.27 & 1.91 & 14.1 \\
\hline & $\mathrm{C} 1$ & $42-70$ & 5.40 & 4.71 & 0.92 & 0.04 & 0.00 & 0.03 & 0.01 & 0.08 & 1.00 & 7.9 \\
\hline & $\mathrm{C} 2$ & $70-120$ & 5.43 & 4.67 & 0.87 & 0.20 & 0.01 & 0.04 & 0.01 & 0.26 & 1.13 & 22.9 \\
\hline & $\mathrm{C} 3$ & $120-180$ & 5.24 & 4.64 & 0.83 & 0.24 & 0.03 & 0.03 & 0.00 & 0.30 & 1.13 & 26.6 \\
\hline \multirow[t]{9}{*}{16} & Ol & $0-1$ & 3.85 & 3.27 & 32.25 & 17.07 & 0.84 & 0.76 & 0.13 & 18.80 & 51.05 & 36.8 \\
\hline & Ofh & $1-4$ & 4.40 & 3.93 & 33.45 & 15.45 & 0.63 & 0.17 & 0.13 & 16.38 & 49.83 & 32.9 \\
\hline & ApEes & $0-5$ & 3.77 & 3.56 & 6.23 & 0.33 & 0.05 & 0.09 & 0.01 & 0.48 & 6.71 & 7.2 \\
\hline & Ap & $5-26$ & 4.51 & 4.00 & 3.44 & 0.20 & 0.03 & 0.04 & 0.01 & 0.28 & 3.72 & 7.5 \\
\hline & BvBhfe & $26-51$ & 5.06 & 4.51 & 1.22 & 0.15 & 0.02 & 0.03 & 0.02 & 0.22 & 1.44 & 15.3 \\
\hline & $\mathrm{C} 1$ & $51-64$ & 5.04 & 4.55 & 0.77 & 0.15 & 0.02 & 0.03 & 0.01 & 0.21 & 0.98 & 21.4 \\
\hline & $\mathrm{C} 2$ & 64-104 & 4.98 & 4.36 & 1.23 & 0.17 & 0.02 & 0.03 & 0.00 & 0.22 & 1.45 & 15.2 \\
\hline & $\mathrm{C} 3$ & $104-160$ & 5.95 & 4.57 & 0.93 & 1.12 & 0.15 & 0.02 & 0.00 & 1.29 & 2.22 & 58.1 \\
\hline & $\mathrm{C} 4$ & $160-200$ & 5.25 & 4.38 & 0.78 & 0.35 & 0.03 & 0.03 & 0.00 & 0.41 & 1.19 & 34.5 \\
\hline
\end{tabular}


Table 3 - cont.

\begin{tabular}{|c|c|c|c|c|c|c|c|c|c|c|c|c|}
\hline \multirow{2}{*}{$\begin{array}{l}\text { The plot } \\
\text { study }\end{array}$} & \multirow[b]{2}{*}{ Horizon } & \multirow{2}{*}{$\begin{array}{l}\text { Depth } \\
{[\mathrm{cm}]}\end{array}$} & \multicolumn{2}{|l|}{$\mathrm{pH}$} & \multicolumn{7}{|c|}{$\left[\mathrm{cmol}_{(+)} \mathrm{kg}^{-1}\right]$} & \multirow[b]{2}{*}{ BS [\%] } \\
\hline & & & in $\mathrm{H}_{2} \mathrm{O}$ & in $\mathrm{KCI}$ & $\mathrm{Hh}^{*}$ & $\mathrm{Ca}^{2+}$ & $\mathrm{Mg}^{2+}$ & $\mathrm{K}^{+}$ & $\mathrm{Na}^{+}$ & $\mathrm{BC}$ & CEC & \\
\hline \multirow[t]{13}{*}{21} & $\mathrm{Ol}$ & $0-1$ & 4.35 & 4.11 & 47.10 & 29.76 & 6.50 & 0.99 & 0.21 & 37.46 & 84.56 & 44.3 \\
\hline & Ofh & $1-2$ & 4.40 & 3.78 & 39.45 & 11.40 & 1.50 & 0.75 & 0.13 & 13.78 & 53.23 & 25.9 \\
\hline & $\mathrm{A}$ & $0-11$ & 4.43 & 3.58 & 8.19 & 0.48 & 0.20 & 0.06 & 0.04 & 0.78 & 8.97 & 8.7 \\
\hline & $\mathrm{ABv}$ & $11-24$ & 4.43 & 4.04 & 3.71 & 0.10 & 0.10 & 0.01 & 0.03 & 0.24 & 3.95 & 6.1 \\
\hline & $\mathrm{Bv}$ & $24-58$ & 5.33 & 4.49 & 1.49 & 0.05 & 0.00 & 0.01 & 0.03 & 0.09 & 1.58 & 5.7 \\
\hline & $\mathrm{C} 1$ & 58-95 & 5.34 & 4.70 & 1.76 & 0.02 & 0.00 & 0.01 & 0.02 & 0.05 & 1.81 & 2.7 \\
\hline & $\mathrm{C} 2$ & $95-101$ & 4.68 & 4.04 & 2.45 & 0.13 & 0.00 & 0.01 & 0.01 & 0.15 & 2.60 & 5.7 \\
\hline & $\mathrm{Mb} 1$ & $101-104$ & 3.79 & 3.44 & 3.87 & 3.99 & 0.20 & 0.05 & 0.02 & 4.26 & 8.13 & 52.4 \\
\hline & Mb2 & $104-108$ & 3.81 & 3.50 & 3.01 & 2.35 & 0.11 & 0.07 & 0.02 & 2.55 & 5.56 & 45.8 \\
\hline & AEesb & $108-125$ & 4.79 & 4.23 & 1.89 & 0.15 & 0.00 & 0.00 & 0.00 & 0.15 & 2.04 & 7.4 \\
\hline & Eesb & $125-131$ & 5.05 & 4.56 & 1.58 & 0.13 & 0.00 & 0.03 & 0.00 & 0.16 & 1.74 & 9.2 \\
\hline & BvBfeb & $131-162$ & 5.60 & 4.91 & 1.73 & 0.80 & 0.01 & 0.03 & 0.01 & 0.85 & 2.58 & 32.9 \\
\hline & $\mathrm{Cb}$ & $162-200$ & 5.26 & 4.78 & 1.01 & 0.11 & 0.00 & 0.03 & 0.00 & 0.14 & 1.15 & 12.2 \\
\hline
\end{tabular}

Explanation: * Hh - hydrolityc acidity, BC - base cations, CEC - cation exchange capacity. BS - base saturation

plant communities like Luzulopilosae-Fagetum or Querco-Pinetum, most of the organic carbon stock is accumulated in soil mineral horizonsat $84 \%$ in site 21 and $82.8 \%$ in study plot 1 a. Comparison of the $1 \mathrm{a}$ and $1 \mathrm{~b}$ research area shows the influence of beech stand on the shaping of organic carbon stocks in forest soils as regards total stocks and soil profile vertical distribution. The sites have two forest stands. The first is a 90 years old (1a) and formed from under brushes and saplings after removal of a 130-year old pine stand planted instead of natural forest stands 42 years ago. The second stand is 42 a year-old pine wood (1b) formed after the complete removal of a c. 130-year old pine stand with under brush with beech saplings, and the same history of utilisation and look as the stand as site 1a stand (Dymitryszyn et al., 2013). The type of forest management in the analyzed sites had large influence on the content and stocks of soil organic carbon and other physico-chemical soil properties (Table 4). Higher organic carbon stocks were noted in the beech stand than in the pine stand sites. The organic carbon content in particular genetic horizons and its stocks are also variably distributed among the stands. In the $1 \mathrm{~b}$ beech stand site, higher stocks of organic carbon were noted in the mineral horizons in comparison to the organic horizons, with a ratio of $82.8 \%$ to $17.2 \%$. In turn, in the pine stand site, higher stocks of organic carbon were noted in the organic horizons (58.4\%) in relation to the mineral horizons (41.6\%). In the studied interval, a significant increase of the content of organic carbon was observed in humus and sideric horizons. Some authors have observed increase of organic carbon content particularly in the surface part of forest soil (Post and Kwon, 2000; Vesterdal et al., 2002). Litter fall and beech leaf decomposition also contributed to the transformation of soil physical-chemical properties. Soil acidity decreased, whereas the content of alkaline cations and total nitrogen increased. These results confirm other authors' reports (Ritter, 2005; Annunzio et al., 2008). The study sites can be considered as reference areas in Forest Carbon Farms for parts of forests with scheduled forest management activities modified to increase the accumulation of organic carbon (additional forestry activities). Instruction no. 2 of the General Director of State Forests of $17^{\text {th }}$ January 2017 (Instruction 2017) recommends increasing under brush cover and changing forest protection style to protect from damage caused by game and other biotic and abiotic factors. The influence of beech under brush on soil organic carbon stocks has been noted in the studied sites. In site 5 significant damage caused by nun moth was observed in 1979-1982, followed by windfall and snow break in the following years (Dymitryszyn et al., 2013). This could have caused a decrease of organic carbon stocks, when compared to site $1 \mathrm{~b}$ with a similar structure of the forest stand in a lower age class with much larger stocks of organic carbon.

The studies have also shown the post-arable influence on organic carbon stocks. In post agricultural soils, organic carbon stock was much lower (the average stock of organic carbon was $55.53 \mathrm{Mg} \cdot \mathrm{ha}^{-1}$ ) than in forest soils that were not subject to agriculture (averagely $101.23 \mathrm{Mg} \cdot \mathrm{ha}^{-1}$ ). Studies have indicated the significant role of forest management and its modifications on the increase of soil organic carbon stock. In the analyzed case, a critical role was played by the introduction of beech forest stands modifying soil sorption complex properties. The results may be a base to conduct a larger-scale project with regard to Instruction no. 2 of the General Director of State Forests of $17^{\text {th }}$ January 2017 (Instruction 2017). It should be emphasized that the project would directly answer the regulations of the Paris Agreement L282/4 of 19.10.2016 on climate change. According to article 5, point 2, the agreement encourages to take actions to implement and support, also through results-based payments, the existing framework as set out in related guidance and decisions already agreed under the Convention for policy approaches and positive incentives for activities relating to reducing emissions from deforestation and forest degradation, and the role of conservation, sustainable management of forests and enhancement 
Table 4

Organic carbon and total nitrogen content, C:N ratio, bulk density and carbon stocks

\begin{tabular}{|c|c|c|c|c|c|c|c|c|c|c|c|}
\hline \multirow{3}{*}{$\begin{array}{l}\text { The } \\
\text { plot } \\
\text { study }\end{array}$} & \multirow{3}{*}{$\begin{array}{l}\text { Genetic } \\
\text { horizon }\end{array}$} & \multirow[t]{2}{*}{ Depth } & \multirow[t]{2}{*}{ Org C } & \multirow[t]{2}{*}{$\mathrm{Nt}$} & \multirow[t]{3}{*}{$\mathrm{C}: \mathrm{N}$} & \multirow{3}{*}{$\begin{array}{l}\mathrm{BD}^{*} \\
\mathrm{~g} \cdot \mathrm{cm}^{-3}\end{array}$} & \multirow[t]{3}{*}{$\mathrm{SIG}^{*}$} & \multicolumn{4}{|c|}{ Stock of org C } \\
\hline & & & & & & & & \multirow{2}{*}{$\begin{array}{l}\text { In horizons } \\
{\left[\mathrm{kg} \cdot \mathrm{m}^{-2}\right]}\end{array}$} & \multirow{2}{*}{$\begin{array}{l}\text { In profile } \\
{\left[\mathrm{kg} \cdot \mathrm{m}^{-2}\right]}\end{array}$} & \multicolumn{2}{|c|}{$\begin{array}{l}\text { In horizons (organic and } \\
\text { mineral) in } \% \text { of stock in profile }\end{array}$} \\
\hline & & $\mathrm{cm}$ & {$\left[\mathrm{g} \cdot \mathrm{kg}^{-1}\right]$} & & & & & & & $\%$ & \\
\hline \multirow[t]{11}{*}{$1 \mathrm{a}$} & $\mathrm{Ol}$ & $0-1$ & 315.6 & 15.2 & 20.8 & 0.2 & 16 & 0.63 & 10.76 & 5.87 & 17.18 \\
\hline & Ofh & $1-3.5$ & 243.4 & 10.6 & 23.0 & 0.2 & & 1.22 & & 11.31 & \\
\hline & A & $0-8$ & 42.4 & 3.4 & 12.5 & 1.31 & & 4.44 & & 41.31 & \\
\hline & $\mathrm{ABv}$ & 8-19 & 14.6 & 1.3 & 11.2 & 1.42 & & 2.28 & & 21.20 & \\
\hline & Bv1 & $19-35$ & 6.9 & 0.8 & 8.6 & 1.42 & & 1.58 & & 14.57 & 82.82 \\
\hline & Bv2 & $35-46$ & 0.9 & 0.1 & 9.0 & 1.43 & & 0.14 & & 1.32 & \\
\hline & $\mathrm{C} 1$ & $46-70$ & 0.7 & 0.1 & 7.0 & 1.50 & & 0.25 & & 2.34 & \\
\hline & C2 & $70-94$ & 0.6 & 0.1 & 6.0 & 1.55 & & 0.23 & & 2.07 & \\
\hline & $\mathrm{C} 3$ & $94-140$ & 0 & 0 & 0 & 1.55 & & 0 & & 0 & \\
\hline & $\mathrm{C} 4$ & $140-190$ & 0 & 0 & 0 & 1.55 & & 0 & & 0 & \\
\hline & $\mathrm{C} 5$ & $190-200$ & 0 & 0 & 0 & 1.55 & & 0 & & 0 & \\
\hline \multirow[t]{8}{*}{$1 b$} & $\mathrm{Ol}$ & $0-1$ & 368.7 & 14.6 & 25.3 & 0.2 & 9 & 0.74 & 8.45 & 8.73 & 58.38 \\
\hline & Ofh & $1-7$ & 349.6 & 14.0 & 25.0 & 0.2 & & 4.20 & & 49.65 & \\
\hline & AEes & $0-10$ & 10.8 & 0.8 & 13.5 & 1.31 & & 1.42 & & 16.74 & \\
\hline & BvBhfe & $10-20$ & 6.6 & 0.5 & 13.2 & 1.42 & & 0.94 & & 11.09 & \\
\hline & Bv1 & $20-50$ & 1.2 & 0.2 & 6.0 & 1.43 & & 0.52 & & 6.09 & 41.62 \\
\hline & Bv2 & $50-76$ & 0.8 & 0.1 & 8.0 & 1.51 & & 0.31 & & 3.72 & \\
\hline & $\mathrm{C} 1$ & $76-108$ & 0.7 & 0.1 & 7.0 & 1.50 & & 0.34 & & 3.98 & \\
\hline & $\mathrm{C} 2$ & $108-180$ & 0 & 0 & 0 & 1.55 & & 0 & & 0 & \\
\hline 2 & $\mathrm{Ol}$ & $0-2$ & 276.5 & 17.2 & 16.1 & 0.2 & 18 & 1.11 & 6.04 & 18.32 & 80.84 \\
\hline & Ofh & $2-10$ & 235.8 & 15.8 & 14.9 & 0.2 & & 3.77 & & 62.51 & \\
\hline & ApEes & $0-21$ & 3.2 & 0.2 & 16.0 & 1.32 & & 0.89 & & 14.7 & \\
\hline & BvBhfe & $21-52$ & 0.6 & 0.2 & 3.0 & 1.45 & & 0.27 & & 4.47 & \\
\hline & C1(dark) & $52-110$ & 0 & 0 & 0 & 1.52 & & 0 & & 0 & 19.16 \\
\hline & C1(white) & $52-110$ & 0 & 0 & 0 & 1.46 & & 0 & & 0 & \\
\hline & $\mathrm{C} 2$ & $110-180$ & 0 & 0 & 0 & 1.60 & & 0 & & 0 & \\
\hline 5 & $\mathrm{Ol}$ & $0-1$ & 372.6 & 15.6 & 23.9 & 0.2 & 10 & 0.75 & 5.73 & 13.01 & 74.77 \\
\hline & Ofh & $1-6$ & 353.6 & 14.3 & 24.7 & 0.2 & & 3.54 & & 61.76 & \\
\hline & ApEes & $0-21$ & 4.0 & 0.4 & 10.0 & 1.38 & & 1.16 & & 20.25 & \\
\hline & BvBhfe & $21-42$ & 0.9 & 0.2 & 4.5 & 1.51 & & 0.28 & & 4.98 & \\
\hline & $\mathrm{C} 1$ & $42-70$ & 0 & 0 & 0 & 1.60 & & 0 & & 0 & 25.23 \\
\hline & $\mathrm{C} 2$ & $70-120$ & 0 & 0 & 0 & 1.60 & & 0 & & 0 & \\
\hline & $\mathrm{C} 3$ & $120-180$ & 0 & 0 & 0 & 1.56 & & 0 & & 0 & \\
\hline 16 & $\mathrm{Ol}$ & $0-1$ & 302.5 & 10.7 & 28.3 & 0.2 & 12 & 0.60 & 4.89 & 14.03 & 45.58 \\
\hline & Ofh & $1-4$ & 298.2 & 9.4 & 31.7 & 0.2 & & 1.79 & & 28.72 & \\
\hline & ApEes1 & $0-5$ & 9.1 & 0.8 & 11.4 & 1.29 & & 0.59 & & 20.25 & \\
\hline & ApEes2 & $5-26$ & 4.3 & 0.5 & 8.6 & 1.33 & & 1.20 & & 4.98 & \\
\hline & BvBhfe & $26-51$ & 2.0 & 0.1 & 20 & 1.43 & & 0.71 & & 0 & 54.42 \\
\hline & $\mathrm{C} 1$ & $51-64$ & 0 & 0 & 0 & 1.51 & & 0 & & 0 & \\
\hline & $\mathrm{C} 2$ & $64-104$ & 0 & 0 & 0 & 1.49 & & 0 & & 0 & \\
\hline & C3 & $104-160$ & 0 & 0 & 0 & 1.59 & & 0 & & & \\
\hline & $\mathrm{C} 4$ & $160-200$ & 0 & 0 & 0 & 1.48 & & 0 & & & \\
\hline 21 & $\mathrm{Ol}$ & $0-1$ & 311.3 & 14.2 & 21.9 & 0.2 & 12 & 0.62 & 11.16 & 5.58 & 8.9 \\
\hline & Ofh & $1-2$ & 185.4 & 10.4 & 17.8 & 0.2 & & 0.37 & & 3.32 & \\
\hline & A & $0-11$ & 15.6 & 1.2 & 13.0 & 1.23 & & 2.11 & & 18.91 & \\
\hline & $\mathrm{ABv}$ & $11-24$ & 7.7 & 0.8 & 9.6 & 1.29 & & 1.29 & & 11.57 & \\
\hline & $\mathrm{Bv}$ & $24-58$ & 1.1 & 0.1 & 11.0 & 1.36 & & 0.51 & & 4.56 & 91.1 \\
\hline & $\mathrm{C} 1$ & $58-85$ & 0 & 0 & 0 & 1.45 & & 0 & & 0 & \\
\hline & $\mathrm{C} 2$ & 95-101 & 2.7 & 0.3 & 9.0 & 1.39 & & 0.22 & & 2.02 & \\
\hline & Mb1 & 101-108 & 271.6 & 23.2 & 11.7 & 0.4 & & 3.26 & & 29.2 & \\
\hline & $\mathrm{Mb} 2$ & $108-108$ & 97.4 & 8.3 & 11.7 & 0.4 & & 1.17 & & 10.47 & \\
\hline & AEesb & $108-125$ & 2.2 & 0.3 & 7.3 & 1.32 & & 0.49 & & 4.42 & \\
\hline & Eesb & $125-131$ & 1.1 & 0.2 & 5.5 & 1.38 & & 0.09 & & 0.82 & \\
\hline & BvBfeb & $131-162$ & 1.4 & 0.2 & 4.7 & 1.51 & & 0.65 & & 5.87 & \\
\hline & $\mathrm{Cb}$ & $162-200$ & 0.6 & 0.2 & 3.0 & 1.60 & & 0.36 & & 3.27 & \\
\hline
\end{tabular}

Explanation*: BD - Bulk density, SIG - Trophic Soil Index 
of forest carbon stocks as well as alternative policy approaches like joint mitigation of climate change and adaptation for the integral and sustainable management of forests (Decision 2016). The scheduled implementation of the concept of Forest Carbon Farms to international economic practice would increase forest significance in the process of stabilizing $\mathrm{CO}_{2}$ concentration in the atmosphere and increasing additional forest ecosystem functions in bearing public burdens (Drabarczyk, 2016). Similar FCF concepts are realized in other countries like Sweden (The Swedish Environmental Protection Agency 2006) or Australia (Website 2).

\section{Conclusions}

1. Beech forest stand formed from undergrowth and saplings after removal of pine stands accumulated over $20 \%$ more organic carbon content.

2. Under a beech stand, much more organic matter is accumulated in mineral horizons than in organic horizons.

3. It seems valid to introduce beech undergrowth and saplings into pine forest stands in succeeding generations.

4. The experiment should applied in a wider scale in Forest Carbon Farms.

6. In post agricultural soils, the stock of organic carbon was much lower (average organic carbon stock at $55.53 \mathrm{Mg} \cdot \mathrm{ha}^{-1}$ ) than in forest soils that were not subject to agriculture (averagely $101.23 \mathrm{Mg} \cdot \mathrm{ha}^{-1}$ ).

\section{References}

Annunzio, R., Zeller, B., Nicolas, M., Dhote, J.F., Saint-Andre, L. 2008. Decomposition of European beech (Fagus sylvatica) litter: Combining quality theory and $15 \mathrm{~N}$ labelling experiments. Soil Biology and Biochemistry 40, 322-333.

Baritz, R., Seufert, G., Montanarella, L., Vanranst, E., 2010. Carbon concentrations and stocks in forest soils of Europe; Forest Ecology and Management 260(3), 262-277.

Bednarek, R., Dziadowiec, H., Pokojska, U., Prusinkiewicz, Z., 2004. Badania ekologiczno-gleboznawcze. [Ecological and soil science of the study] Warszawa. Wydawnictwo PWN: 344 ss.

Biały, K., Brożek, S., Chojnicki, J., Czępińska-Kamińska, D., Januszek, K., Kowalski, A., Krzyżanowski, A., Okołowicz, M., Sienkiewicz, A., Skiba, S., Wójcik, J., Zielony, R., 2000. Klasyfikacja gleb leśnych Polski. [Classification of forest soils of Poland]. Centrum Informacyjne Lasów Państwowych, Warszawa: 127 ss.

Borek, S., 1983. Niektóre właściwości fizyczne gleb Rezerwatu Granica w Kampinoskim Parku Narodowym. Wpływ działalności człowieka na środowisko glebowe w Kampinoskim Parku Narodowym. [Selected physical properties of soils in the Granica Reservation in the Kampinoski National Park. Influence of human activity on the soil environment in the Kampinoski National Park] Wyd. SGGW-AR, Warszawa: 73-80.

Decision 16/CMP.1 of 21 May 2013 on the rules of reporting and activity plans related to the emmission and absorption of greenhouse gases due to land-use, land-use change and forestry.

Decision Council (EU) 2016/1841 of 5 October 2016 on the conclusion, on behalf of the European Union, of the Paris Agreement adopted under the United Nations Framework Convention on Climate Change
Drabarczyk, J., 2016. Zatrzymać węgiel w lesie [Retaining carbon in forests] w: Głos lasu, numer 1 (543) styczeń 2016.

Dymitryszyn, I., Szyszko, J., Rylke, J., 2013. Terenowe metody oceny i wyceny zasobów przyrodniczych. [Field methods of assessing and valuation of natural resources] Wydawnictwo SGGW. 264 ss.

Ilmurzyński, E., Włoczewski, T., 2003. Hodowla lasu. [Forest cultivation] Państwowe Wydawnictwo Rolnicze i Leśne. 539 ss.

IUSS Working Group WRB, 2015. World Reference Base for Soil Resources 2014, update 2015. International soil classification system for naming soils and creating legends for soil maps. World Soil Resources Reports No. 106. FAO, Rome.

Jandl, R., Linder, M., Vesterdal, L., Bram, B., Baritz, R.., Hagendorf, F., Johnson, D., Minkkinen, K., Byrne, K., 2007. How strongly can forest management influence soil carbon sequestration? Geoderma 137, 253-268.

Janowska, E., Czępińska-Kamińska, D., 1983. Kształtowanie się właściwości sorpcyjnych ektopróchnicy niektórych gleb KPN. [Shaping of the sorption properties of ectohumus in some soils of the Kampinoski National Park] (w) Wpływ działalności człowieka na środowisko glebowe w Kampinoskim Parku Narodowym. Wyd. SGGW: 47-58.

Jobbagy, E.G., Jackson, R.B., 2000. The Vertical Distribution of Soil Organic Carbon and its Relation to Climate and Vegetation, Ecological Applications 10(2), 423-436

Karczewska, A., Szopka, K., Bogacz, Kabała, C., Duszyńska, D., 2007. Rozważania nad metodyką monitoringu gleb strefy leśnej Karkonoskiego Parku Narodowego (KPN) - w świetle zróżnicowania właściwości tych gleb. [Speculations on the methods of monitoring soils in the forest zone of the Karkonoski National Park] - In: Štursa J. \& Knapik R. (eds), Geoekologické problémy Krkonoš. Sborn. Mez. Věd. Konf., říjen 2006, Svobodan. Úpou. Opera Corcontica 44, 1, 95-105

KOBiZE, 2016. Report entitled Analysis of the possibilities of using absorption to report greenhouse gases in the 2030 perspective, Warsaw, 29 February 2016, p. 3.

Statement of the Commission of the European Parliament, of the Council, of the European Economic-Social Commitee and the Regions Commitee, of 13 March 2012 on impact assessment of the role of land use, land use change and forestry (LULUCF) in the EU's climate change commitments.

Kondras, M., Czępińska-Kamińska, D., Sienicka, P., Otręba, A., Torzewski, K., Oktaba, L. 2012. Zapas węgla organicznego gleb leśnych zespołu kontynentalnego boru mieszanego świeżego w Kampinoskim Parku Narodowym [Organic carbonstock in forest soils of the continental mixed fresh coniferous forest assemblage in the Kampinoski National Park], Roczniki Gleboznawcze - Soil Science Annual 63(4), 26-33.

Lasota, J., Błońska, E., 2013. Siedliskoznawstwo leśne na nizinach i wyżynach Polski. [Forest habitats in Polish lowlands and highlands] Wydawnictwo Uniwersytetu Rolniczego w Krakowie: 25-42.

Ostrowska, A., Gawliński, S., Szczubiałka, Z., 1991. Metody analizy i oceny właściwości gleb i roślin. [Methods of analysis and assessment of soil and plant properties] Warszawa, Instytut Ochrony Środowiska, 334 ss.

Paris Agreement, 2016. Official Journal of the European Union of 19 october 2016, L282/4.

Post, W.M., Kwon, K.C., 2000. Soil carbon sequestration and land-use change: processes and potential. Global Change Biology 6, 317-327.

Ritter, E., 2005. Litter decomposition and nitrogen mineralization in newly formed gaps in a Danish beech (Fagus sylvatica) forest. Soil Biology and Biochemistry 37, 1237-1247.

Schlesinger, W.H., 1997. Biogeochemistry, an analysis of global change. Academic Press, San Diego, California, USA

Stendhal, J., Johansson, M.-B., Eriksson, E., Langvall, O., 2010. Soil organic carbon in Swedish spruce and pine forests-differences in stock levels and regional pattern. Silva Fennia 33(1), 5-21. 
Szyszko, J., Dymitryszyn, I., Szwerk, A., Szyszko-Podgórska, K., Jojczyk, A., Bodzenta, M., Sałek, P., Pliszka, P., 2019. „Las dla ludzkości w Tucznie”. Cz. 1 - „Forest for humanity in Tuczno”. Part 1. Wydawnictwo SGGW, 2019.

Polish Soil Science Society, 2009: Klasyfikacja uziamienia gleb i utworów mineralnych - PTG 2008. Soil Science Annual 60( 2), 5-16.

Polish Soil Classification (Systematyka Gleb Polski), 2019, Polskie Towarzystwo Gleboznawcze, Komisja Genezy, Klasyfikacji i Kartografii Gleb, Warszawa.

The Swedish Environmental Protection Agency., 2006. The Integration of LULUCF in the EU's Emissions Trading Scheme to mitigate Climate Change, Stockholm .
Vesterdal, L., Ritter, E., Gundersen, P., 2002. Change in soil organic carbon following afforestation of former arable land. Forest Ecology and Management 169, 137-147.

Instruction no. 2 of the General Director of State Forests of 17 January 2017 on the realization as a joint venture of organizational units of State Forests of a pilot development project "Forest Carbon Farms"

Website 1: https://www.bdl.lasy.gov.pl/portal/k

Website 2:https://www.bdl.lasy.gov.pl/portal/mapy

Website3: https://www.environment.gov.au/climate-change/carbon-neutral/carbon-neutral-program

\section{Wpływ gospodarki leśnej na zapasy węgla organicznego w glebach}

\author{
Słowa kluczowe \\ Gospodarka leśna \\ Zapas węgla \\ Sekwestracja węgla \\ Gleby
}

\section{Streszczenie}

W pracy przeprowadzono analizy fizyko-chemiczne gleb na sześciu stanowiskach różnych siedlisk w Nadleśnictwie Tuczno. Podstawowym celem badań było określenie wpływu żyzności naturalnego siedliska oraz sposobu użytkowania lasu i historii użytkowania w przeszłości na sekwestrację dwutlenku węgla w postaci węgla organicznego na hektarze. Podjęto próbę oszacowania $\mathrm{w}$ każdym poziomie genetycznym oraz w całym profilu glebowym wybranych gleb zapasu węgla organicznego oraz obliczono wskaźnik siedliskowy indeks glebowy SIG. W badanych glebach analizowano skład granulometryczny, zawartości węgla organicznego oraz azotu ogólnego, stosunek C:N i właściwości sorpcyjne. Drzewostan bukowy powstały z podszytów i podrostów po usunięciu drzewostanu sosnowego zgromadził ponad $20 \%$ więcej węgla organicznego niż drzewostan sosnowy o takiej samej historii powstania. Zauważa się wpływ podszytu bukowego na zwiększenie zapasów węgla organicznego w glebach. Badania wykazały wpływ gospodarki leśnej na zapasy węgla organicznego $\mathrm{w}$ badanych glebach. W glebach porolnych zasoby węgla organicznego były znacznie niższe (średnie zapasy węgla organicznego wyniosły 55,53 thha ${ }^{-1}$ ) niż w glebach leśnych, które nigdy nie były uprawiane rolniczo (średnio 101,23 t·ha ${ }^{-1}$ ) 